\title{
Author's reply: Is there a need for special treatment of refugees at hospital admission?
}

VA Kempf, $U$ Heudorf ${ }^{2}$, on behalf of the authors of the original articles ${ }^{34}$

1. Institute for Medical Microbiology and Infection Control, University Hospital Frankfurt am Main, Germany

2. Public Health Department, Frankfurt am Main, Germany

3. http://www.eurosurveillance.org/ViewArticle.aspx?Articleld=21353

4. http://www.eurosurveillance.org/ViewArticle.aspx?Articleld=21352

Correspondence: Volkhard A. J. Kempf (volkhard.kempf@kgu.de); Ursel Heudorf (ursel.heudorf@stadt-frankfurt.de)

Citation style for this article:

Kempf V, Heudorf U, on behalf of the authors of the original articles. Author's reply: Is there a need for special treatment of refugees at hospital admission?. Euro Surveill. 2016;21(7):pii=30138. DOI: http://dx.doi.org/10.2807/1560-7917.ES.2016.21.7.30138

Article submitted on 16 February 2016 / accepted on 18 February 2016 / published on 18 February 2016

To the editor: We would like to thank Walter and colleagues for their comment [1] on our respective investigations published in Eurosurveillance [2,3]. While we agree with many of the statements made, we would nevertheless like to clarify the following points:

The Robert Koch Institute published recommendations for multidrug-resistant organisms (MDRO) screening of refugees on hospital admission already in October 2015 [4]. This document stated that according to the recommendations of the German Commission of Hospital Hygiene and Infection Prevention screening for multidrug-resistant organisms (MDRO) on hospital admission is necessary for patients coming from regions with high prevalence rates for MDRO, with previous contact to the health system in their country of origin or on route. Furthermore it points out that screening should encompass meticillin-resistant Staphylococcus aureus (MRSA) and carbapenem-resistant bacteria, only [5].

Infection control measures always represent a tradeoff between patient safety and best medical treatment. We have shown that (i) the prevalence of MRSA is significantly higher in refugees (REF) (5.6\%) than in a comparison group of resident population not admitted from a refugee accommodation (NREF) (1.2\%) which itself justifies pre-emptive isolation, (ii) the prevalence of extended spectrum beta-lactamase (ESBL)-producing bacteria is significantly higher in REF which indeed has no infection control relevance, (iii) the prevalence of MDRGN with additional resistance to fluoroquinolones (so called 3MRGN in Germany) is significantly higher in REF which implies clearly consequences for hospital hygiene measures at least in special settings, e-g., intensive care units and (iv) the prevalence of carbapenem-resistant MDRGN strains (so called 4MRGN in Germany) in REF also, even if only slightly higher.

MDRO prevalence varies between distinct groups of patients and appropriate risk assessment has been established at Frankfurt University Hospital since five years e.g. for patients returning from high prevalence countries who have had contact with foreign healthcare systems. Increased MRSA, and, possibly also increased 3 MRGN rates justify screening procedures and isolation in certain risk groups. Identification of risk groups and introduction of adequate infection control measures are genuine duties of hospital infection control and are uncomfortable, may affect medical treatment and are certainly costly. However, we feel that our approach is necessary to ensure best medical practice and safety for all of our patients regardless of their country of origin and without stigmatisation.

\section{Conflict of interest}

None declared.

Authors' contributions

UH: literature work, writing. VK: literature work, writing.

References

1. Walter J, Haller S, Hermes J, Arvand M, Abu Sin M, Eckmanns T. Letter to the editor: Is there a need for special treatment of refugees at hospital admission? Euro Surveill. 2016;21(7):pii=30137. DOI: http://dx.doi.org/DOI: 10.2807/1560-7917.ES.2016.21.7.30137

2. Reinheimer C, Kempf VA, Göttig S, Hogardt M, Wichelhaus TA, O'Rourke F, et al. Multidrug-resistant organisms detected in refugee patients admitted to a University Hospital, Germany June-December 2015. Euro Surveill. 2016;21(2):30110. DOI: 10.2807/1560-7917.ES.2016.21.2.30110 PMID: 26794850

3. Heudorf U, Krackhardt B, Karathana M, Kleinkauf N, Zinn C. Multidrug-resistant bacteria in unaccompanied refugee minors arriving in Frankfurt am Main, Germany, October to November 2015. Euro Surveill. 2016;21(2):pii=30109. DOI: http://dx.doi. org/10.2807/1560-7917.ES.2016.21.2.30109

4. Robert Koch Institute (RKI). Screening von Asylsuchenden auf Multiresistente Erreger (MRE) Stellungnahme des Robert Koch-Instituts. [Screening of asylum seekers for multidrug resistant bacteria: statement of the Robert Koch-Insitute.] Berlin: RKI; 9 October 2015. German. Accessed from: http://www.rki.de/DE/Content/Gesundheitsmonitoring/ Gesundheitsberichterstattung/GesundAZ/Content/A/ 
Asylsuchende/Inhalt/MRE-Screening Asylsuchende.pdf?

blob=publicationFile on 5 December, 2015. No longer available, replaced online by [5].

5. Robert Koch Institute (RKI). Stellungnahme des Robert

Koch-Instituts zu Frage des Screenings von Asylsuchenden auf Multiresistente Erreger (MRE). [Statement of the Robert Koch Institute regarding screening of asylum seekers for multidrug resistant bacteria.] Berlin: RKI; 28 January 2016.

German. Available from: https://www.rki.de/DE/Content/

Gesundheitsmonitoring/Gesundheitsberichterstattung/

GesundAZ/Content/A/Asylsuchende/Inhalt/MRE-Screening

Asylsuchende.pdf?__blob=publicationFile

\section{License and copyright}

This is an open-access article distributed under the terms of the Creative Commons Attribution (CC BY 4.0) Licence. You may share and adapt the material, but must give appropriate credit to the source, provide a link to the licence, and indicate if changes were made.

This article is copyright of the authors, 2016. 